\title{
Mountain hazards: reducing vulnerability by adapted building design
}

\author{
Markus Holub $\cdot$ Jürgen Suda $\cdot$ Sven Fuchs
}

Received: 7 April 2011/Accepted: 6 October 2011/Published online: 28 October 2011

(C) The Author(s) 2011. This article is published with open access at Springerlink.com

\begin{abstract}
Despite the long tradition of technical mitigation on a catchment scale in European mountain regions, losses due to mountain hazards are still considerably high in number and monetary loss. Therefore, the concept of technical mitigation had been supplemented by land-use planning and, more recently, local structural protection. Local structural protection includes measures directly implemented at or adjacent to endangered objects, and has proven to be particularly cost-effective with respect to integral risk management strategies. However, the effect of local structural protection in reducing the vulnerability of elements at risk, and the associated consequences with respect to a
\end{abstract}

Electronic supplementary material The online version of the article (doi:10.1007/s12665-011-1410-4) contains supplementary material available to authorized users.

M. Holub ( $\square)$

Risk Consult Sicherheits- und Risiko-Managementberatung

GmbH, Engelsberggasse 4/2, 1030 Vienna, Austria

e-mail: m.holub@riskconsult.at

J. Suda

Institute of Structural Engineering, University of Natural

Resources and Life Sciences, Peter Jordan Str. 82,

1190 Vienna, Austria

J. Suda

Alpinfra, Consulting-Engineering Gmbh, Kuefsteingassee 15-19, 1190 Vienna, Austria

S. Fuchs

Institute of Mountain Risk Engineering, University of Natural Resources and Life Sciences, Peter Jordan Str. 82,

1190 Vienna, Austria

S. Fuchs

Research Laboratory for Snow Avalanches and Debris Flows, Faculty of Geography, Lomonosov Moscow State University, Leninskie Gory 1, 119991 Moscow, Russian Federation reduction of structural vulnerability have not been quantified so far. Moreover, there is a particular gap in quantifying the expenditures necessary for local structural protection measures. Therefore, a prototype of residential building adapted to mountain hazards is presented in this study. This prototype is equipped with various constructional elements to resist the incurring impact forces, i.e., of fluvial sediment transport and of snow avalanches. According to possible design loads emerging from these hazard processes, the constructive design necessary is presented, and the amount of additional costs required for such an adaptation is presented. By comparing these costs with quantitative loss data it is shown that adapted building design is particularly effective to reduce the consequences of low-magnitude, high-frequency events in mountain regions.

Keywords Mountain hazards - Vulnerability · Structural protection $\cdot$ Risk management

\section{Introduction}

In the recent years, increasing numbers of natural hazards and associated losses have shown to the European Commission and the Member States of the European Union the paramount importance of the natural hazards issue for the protection of the environment and the citizens (Barredo 2007). There is a strong scientific evidence of an increase in mean precipitation, and magnitude and frequency of extreme precipitation events, which implies that extreme flood events might become more frequent (Christensen and Christensen 2003; Kundzewicz et al. 2005; Solomon et al. 2007; Keiler et al. 2010). In parallel, exposure to floods might increase across Europe as well as flood vulnerability due to population and wealth moving into flood-prone 
areas. Such issues have already been reported due to a global increase in population and the associated shift in economic activities (e.g., O'Keefe et al. 1976; Susman et al. 1983). Thus, even without taking climate change into account an increase of flood disasters in Europe might be foreseeable (Mitchell 2003). However, alternative sources reporting on quantifying studies both on flood hazards at a continental level (US and Europe) as well as at a regional level suggested a trend in the opposite direction. Firstly, as discussed in Smith and Petley (2009) and confirming earlier reports within the development context by Guha-Sapir and Below (2002) as well as within the global effort to reduce losses (White 1994), the key point is to be aware of the levels of uncertainty attached to loss data. Secondly, even if flood damages continued to increase despite extensive flood management efforts since 1900, particularly when measured in constant currency units, the trend is not as obvious once normalized. If the flood data related to the US are presented in terms of damage per unit wealth, a slight and statistically insignificant downward trend is observed (Loucks and Stedinger 2007), which suggests that floods might have a lessening or neutral impact on the overall personal wealth of citizens in the US over the course of the past decades. Some other studies have focused on regions with similar economic susceptibility than the US, such as Canada (Etkin et al. 2003) and Europe (Becker and Grünewald 2003; Mudelsee et al. 2003; Barredo 2007). Since floods were a substantial hazard in Europe over the past centuries some inventories exist on the temporal distribution of such events. However, there is no comprehensive or standardized individual database for such losses in Europe. Hence, available information is relatively sparse (Mitchell 2003). Mudelsee et al. (2003) concluded from a hydro-meteorological point of view by an analysis of flood magnitudes that there is no evidence from the observations for recent upward trends in the occurrence of large flood events in central Europe. Similarly, Barredo (2009) concluded by using available information from databases such as EM-DAT and NATHAN, that no clear positive trend in flood losses in Europe exists if they are normalized by eliminating the socio-economic influence of growing exposure in areas affected.

Nevertheless, these circumstances have produced a reaction in the European Commission, and a Directive on the assessment and management of flood risks addressed to the Member States was issued (Commission of the European Communities 2007) as one of the three components of the European action programme on flood risk management (Commission of the European Communities 2004). Within this directive, it has been officially acknowledged for the first time that flood events (defined in its broadest sense including torrent processes) are natural phenomena which cannot be prevented. Such events have the potential to severely compromise economic development and undermine the economic activities of the community due to an increase of human activities in floodplains and the reduction of the natural water retention by land use activities. As a result, an increase in the likelihood and adverse impacts of flood events is expected. Therefore, concentrated action is needed at the European level to avoid severe impacts on human life and property.

\section{Mountain hazards}

Besides many national and European efforts to reduce natural hazard impact on society, considerable damage has still occurred in the recent years in European mountain regions. Thereby, greater availability of information of natural hazard occurrence both on a scientific basis and also due to broader media coverage resulted in an increase of hazard awareness on a societal level, in particular due to a perceived increase in property damage and fatalities. The increased public awareness has often been misconstrued as an indication for increased frequency and magnitude of events which will trigger the potential increase in losses. It is still under debate, however, to which extent recent increases in damage ratios can be related to changing process behavior and thus increased magnitude and frequency, and to which extent these developments are a result from increased utilization of areas prone to hazardous events for human settlement, economic activities and infrastructure corridors. Therefore, both of these possibilities need further research efforts in order to allow for an economically efficient and socially acceptable way of dealing with natural hazards, in particular with respect to the densely populated mountain regions of Europe.

During the last decades, an increase in land-use activity could be observed in European mountain regions. Taking the Republic of Austria as an example, settlements have been expanded, leading to extensive land consumption and associated population growth. Since 1970s, the average useable living space increased from $22 \mathrm{~m}^{2}$ per person in 1972 to $38 \mathrm{~m}^{2}$ in 2001 (Statistik Austria 2004). As a major part of Austria is located in mountain areas above $1,000 \mathrm{~m}$ a.s.l. (this is approximately $36 \%$ of Austria's territory, and approximately 19\% of Austria's territory is located higher than 1,500 $\mathrm{m}$ a.s.l.), areas suitable for permanent settlement are limited. In the entire country, $37.2 \%$ of the land area is suitable for permanent settlement and associated economic activities, while in some Federal states, the values remain noticeably below. Due to this scarcity, land use activities have repeatedly been extended into areas which are endangered by natural hazards such as mass movements, torrent processes, and avalanches. As a consequence, property values prone to these processes increased accordingly. 
Accordingly, an increase in losses due to hazard processes has often been claimed in the recent years as a result of the occurrence of harmful events. However, such statements were hardly quantifiable so far, only few studies addressed the development of natural hazard events and associated losses in alpine countries. These studies were mostly focused on distinct events or reference periods, not on assessing the topic from a broader point of view by compiling a comprehensive database, such as e.g., SLF (2000), Nöthiger et al. (2002), Fuchs and Bründl (2005), and Hilker et al. (2009) for Switzerland, and EmbletonHamann (1997), Fliri (1998), Luzian (2002), and Fuchs (2009) for Austria.

Though, with respect to the concept of integral risk management (Fell et al. 2008), such information is required in order to be able to plan and implement sustainable mitigation strategies. Sustainable mitigation strategies, as outlined by Holub and Fuchs (2009) in more detail, have to be pillared on a complementary multiplicity of risk treatment options acting upon the maxim of cost-efficiency in relation to the targeted expenditures and the aspired decrease in risk. Given the significance of these expenditures, risk-based appraisal of the costs and benefits (in terms of risk reduction) of major capital works is now customary in many alpine countries (Haering et al. 2002; BMLFUW 2005, 2006).

\section{Vulnerability}

Following the axiom that natural hazard risk is a function of hazard and consequences (Varnes 1984; Fell et al. 2008), the ability to determine vulnerability is an essential step for reducing these consequences and therefore natural hazard risk. The approach of structural vulnerability is focusing on impact intensity and structural susceptibility of elements at risk, ranging from 0 (no damage) to 1 (complete destruction). From this technical point of view, as a general rule vulnerability assessment is based on the evaluation of parameters and factors such as building types, construction materials and techniques, state of maintenance, and presence of protection structures (Fell et al. 2008). For this reason, vulnerability values describe the susceptibility of elements at risk facing different process types with different spatial and temporal distributions of process intensities (e.g., flow depths, accumulation heights, flow velocities and pressures, Fuchs et al. 2007a, b; Holub and Fuchs 2008).

If vulnerability is considered as a functional relationship between process magnitude or intensity, the resulting impact on structural elements at risk, and exposed values, vulnerability is related to the susceptibility of physical structures and is defined as the expected degree of loss resulting from the impact of a certain (design) event on the elements at risk.
With respect to the hazardous processes, empirical parameters such as magnitude and frequency have to be evaluated based on probability theory. Thereby the magnitude-frequency concept plays a key role. When the activity of different hazard processes is compared on a given timescale some processes appear to operate continuously while others operate only when specific conditions occur.

By applying the concept of structural vulnerability, from an engineering point of view, considerable areas in European mountain regions are vulnerable to hazard processes (Fuchs 2009). Even though the theory of vulnerability has been subject to extensive research and numerous practical applications over the past decades, considerable gaps still exist with respect to standardized functional relationships between impacting forces due to occurring hazard processes and the structural damage caused (Fuchs et al. 2007b; Papathoma-Köhle et al. 2011). For a major part these gaps result from the overall lack of data, in particular concerning: (1) losses caused by mountain hazards as a result of existing empirical classifications of damages, and (2) measurements of impact forces that caused these losses. Recently, promising approaches for a quantification of vulnerability have been made by Wilhelm (1997), Borter (1999), Barbolini et al. (2004) and Keiler et al. (2006) with respect to avalanches and rock fall processes, respectively. However, sound suggestions for landslides and torrent processes are still largely unavailable, even if these processes caused major losses in the Alps in the recent years (Fuchs et al. 2007a; Fuchs 2009; Totschnig et al. 2011). Although such empirical relationships become increasingly important in determining the vulnerability of structural elements at risk, the results only mirror the average expected systems behavior (expected destruction due to impacting forces) for a specific setting, e.g., the entire area of a torrent fan presumably affected by a defined 1 in 150 year event.

In addition, the analysis of empirical data had shown that the vulnerability of buildings affected by medium hazard intensities (e.g., 1.00-1.50 m deposition height for torrent processes) is highly dependent on whether or not the entrained material harms the interior of the building (i.e., by an intrusion of material through openings such as doors, wells and windows, Fuchs 2009). These findings support previous work carried out by Romang et al. (2003). Consequently, local protection measures such as deflection walls and specially designed closure structures for at-grade openings definitely play a major role in reducing the vulnerability of buildings, particularly with respect to low and medium process intensities (Fuchs et al. 2007b).

Local structural protection measures which are implemented directly at or adjacent to endangered objects might therefore be a valuable and serious alternative with respect to reducing vulnerability within the concept of integral risk management (e.g., Johnson et al. 2005). However, the 


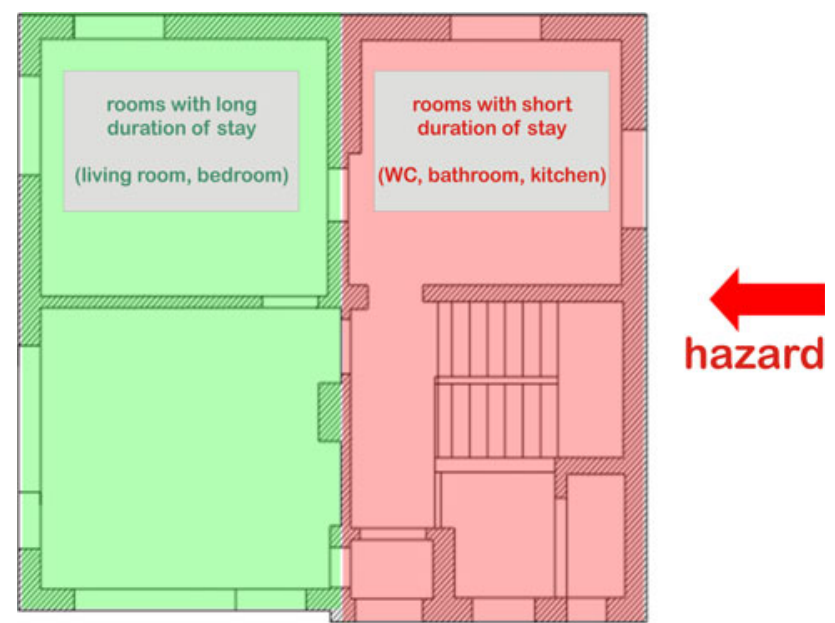

Fig. 1 Distribution of the different rooms according to occupancy time and hazard potential (Holub and Hübl 2008)

effect of local structural protection in reducing susceptibility of values at risk has not been quantified satisfyingly so far (Holub and Hübl 2008), even if the positive effect in reducing vulnerability seems to be obvious. Local structural protection additionally seems to be economically efficient, as recently shown by Holub and Fuchs (2008) with respect to torrent hazards. To decrease the vulnerability of a building it is generally aimed at a combination of adapted construction design and appropriate interior use. Such an appropriate interior design is defined as a room layout which is modified according to possible hazard impacts. This modification is mainly based on the idea of allocating rooms according to e.g., occupancy time of the inhabitants in order to reduce possible threats and losses (Fig. 1). Adapted construction design, in contrast, is rather based on structural enforcements, and therefore targeted at a strengthening of the building envelope by local structural protection.

Local structural protection, namely constructive preventive measures, can be either performed as enclosing structure or as structure directly connected to the building. Such enclosing structures are defined as measures surrounding elements at risk but which are not connected to them. These seem to be very effective since they prevent direct hazard impacts on the building envelope, while structures directly connected to the building envelope in principal generate an increased resistance of the construction; furthermore, they are less land-consuming. However, a combination of both alternatives is anticipated to decrease the level of vulnerability (Holub and Hübl 2008).

Local structural protection measures can be distinguished and classified according to their applicability for protection against hazard processes, their location with respect to the element at risk, as well as their construction type and material used. A further differentiation is according to the permanent or temporal implementation, such as permanent concrete walls or mobile flood protection. Considering the possible impacts of natural hazards, different construction materials show different performance and resistance. Consequently, a process-specific risk assessment, carried out at the earliest possible conceptual design stage and focusing on impact forces, vulnerability as well as damage patterns, will result in an appropriate protection concept (FEMA 1998; Holub and Hübl 2008; Renfroe and Smith 2010). Therefore, information on both, hazard impacts and corresponding loads on the building envelope is necessary.

Taking these findings as a basis, we will present a prototype of residential building typical for European mountain regions and adapted to mountain hazard processes. In particular, this prototype is equipped with various constructional elements which are able to resist the impact forces of hazardous events, i.e., fluvial sediment transport related to torrents, and snow avalanches. Therefore, we will start with a brief overview on studied hazard processes. Thereafter, we focus on (1) possible loads emerging from these hazardous processes and impacting the building envelope (2) the constructive design necessary to resist the loads, and (3) the amount of additional costs necessary for such an adaptation.

\section{Hazard processes}

Within this paper two major hazard categories occurring in mountain areas worldwide but also on the European level are considered: fluvial sediment transport related to torrents, and snow avalanches.

The term torrent refers to steep rivers within a mountain environment and is defined as a constantly or temporarily flowing watercourse within small catchment areas and characterized by changing perennial or intermittent discharge and flow conditions (ONR 2009). Torrent events include a process group with a variety of different characteristics including discharge composed from pure water runoff, discharge with variable sediment concentration and debris flows (Costa 1984). Fluvial sediment transport is characterized by a lower sediment concentration than debris floods and debris flows ( $<40 \%$ by weight Costa 1988$)$.

Fluvial sediment transport and related torrent processes cause static or dynamic impacts originating from flow conditions and the respective amount of transported solids. With respect to scale, process impacts may include surface as well as channel runoff, accompanied by erosion and deposition phenomena of different magnitude (Fuchs et al. 2008). The major process patterns result in possible intrusion of water and solids through the building openings and the sewage system, causing damage to the interior of the 


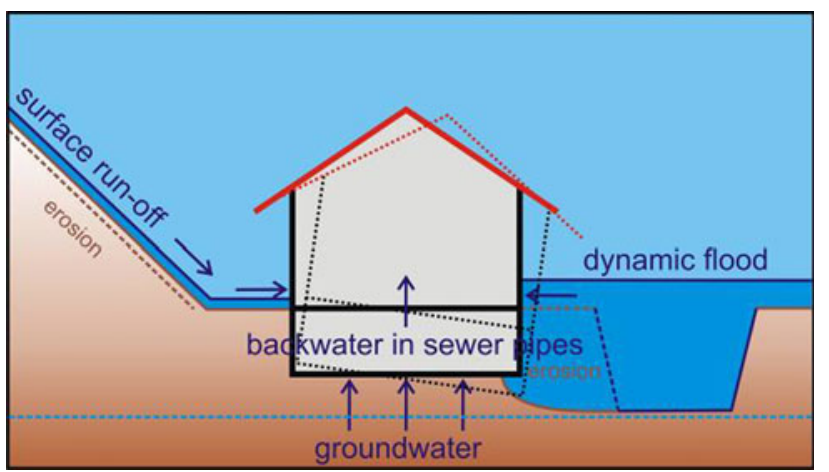

Fig. 2 Damage patterns due to torrent processes (Holub and Hübl 2008)

buildings, apart from possible buoyancy as well as erosion processes resulting in subsidence or even tilting, endangering the stability of the building (Fig. 2).

Snow avalanches are fast-moving mass movements within a mountain environment and are defined as gravitydriven snow masses, moving along a certain track downwards slopes with a dislocation distance $>50 \mathrm{~m}$ (McClung and Schaerer 1993). According to the mechanisms of flow, snow avalanches are regularly distinguished into dense flow avalanches, which may contain additional solids such as rock fragments and logs, and powder avalanches (Keylock 1997; Bründl et al. 2010). Elements at risk located in the deposition area are influenced by two major processes, the air pressure plume in front of a powder avalanche and the snow in motion that exerts high impact pressure on objects located in the runout path (Sovilla et al. 2008).

Avalanches with their dense and powder snow part may affect buildings due to incurring high pressure loads and suction effects to the walls and the roof. Impacts originating from the dynamic or static load of snow and transported solids jeopardize the stability of the building (Fig. 3). Furthermore, snow and solid intrusion through the building openings may occur which will lead to considerable damage inside the buildings.

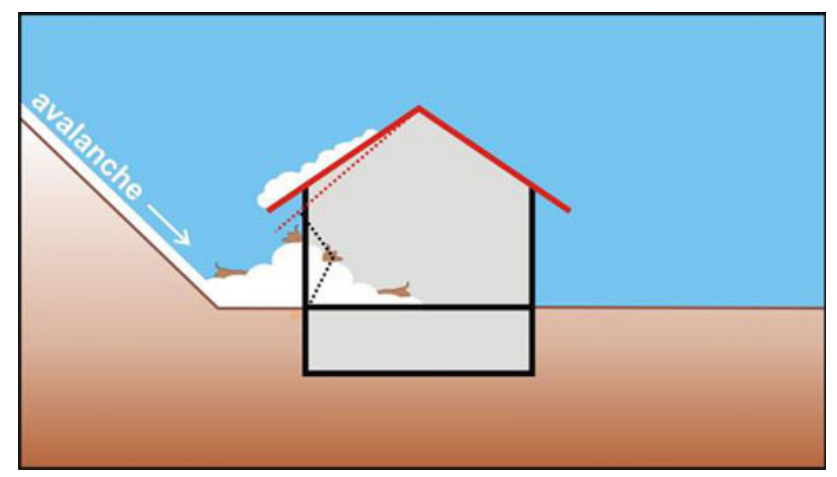

Fig. 3 Damage patterns due to snow avalanches (Holub and Hübl 2008)
In the following section, the loads resulting from fluvial sediment transport related to torrents, as well as loads resulting from snow avalanches are presented. Additionally insights in the general building design criteria are provided.

\section{Loads on the building envelope}

In general, building design criteria have to rely on the following set of design loads, (1) in order to take into account the dead load of the structure (weight of all materials of construction incorporated into the building), (2) to take into account the maximum possible live load (result of the occupancy of a structure), (3) load assumptions resulting from the impact of wind storm, and (4) the assumed static snow load with respect to the design criteria of the truss. Furthermore, (5) the design loads resulting from fluvial sediment transport, and (6) the design loads for snow avalanches (dense part and powder part) were calculated.

\section{Dead load of the structure}

To take into account the dead load of the structure under consideration, the characteristic tare weights were taken from the respective Austrian building code ÖNORM B 1991-1-1 (ON 2003, 2006a). This building code provides design guidance and actions for the structural design of buildings and civil engineering works including geotechnical aspects for the densities of construction materials and stored materials, for the self-weight of construction works, and for imposed loads for buildings.

\section{Live load}

The live load of the floor slab (first and second floor) were calculated by applying ÖNORM B 1991-1-1 (ON 2006a) with $n_{1}=2.0 \mathrm{kN} / \mathrm{m}^{2}$ for the category of residential buildings, $n_{2}=1.5 \mathrm{kN} / \mathrm{m}^{2}$ for the walkable attic story, and $n_{3}=3.0 \mathrm{kN} / \mathrm{m}^{2}$ for the staircase.

\section{Impact of windstorm}

The impact of windstorm on the structure was calculated by applying ÖNORM EN 1991-1-4 and the national specifications ÖNORM B 1991-1-4 (ON 2005a, 2006b). The basic peak gust pressure was calculated with $q_{b, 0}=0.46 \mathrm{kN} / \mathrm{m}^{2}$ resulting from the local wind conditions in mountain valleys of Austria.

To calculate the design loads, the walls and the roof were classified into sections A to J (see Fig. 4), and different pressure coefficients $c_{p}$ were assigned. With respect to the roof, the design loads 1-4 have to be calculated separately by the addition of either DL1 and DL2, 

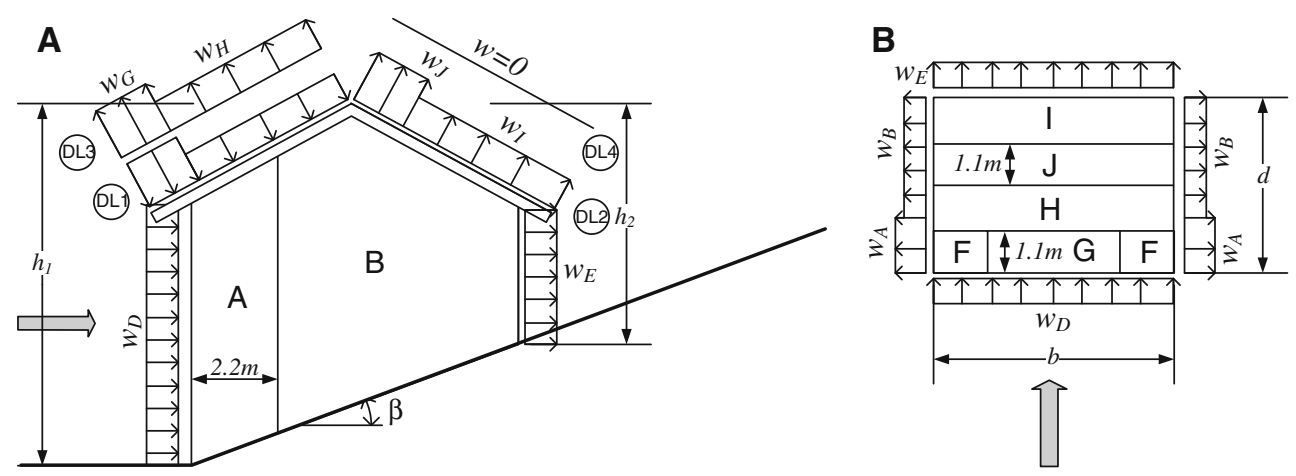

Fig. 4 Structural system for windstorm impacting a building. DL1 load factor 1, DL2 load factor 2, DL3 load factor 3,DL4 load factor 4, $w_{A \ldots J}$ wind load, $\beta$ inclination of the slope, $h_{1,2}$ building height 1 and

DL1 + DL4, DL2 + DL3 or DL3 + DL4. The flow direction of the wind storm was assumed to affect the building from the valley-side.

In analogy to the windstorm loads, design loads for the powder part of snow avalanches were calculated, while the flow direction of the powder part was assumed to affect the building from the hillside.

In Table 1, the assigned pressure coefficients are shown for both, wind storm and powder avalanches (ON 2005b). The pressure coefficients $C_{p e, 10}$ are related to the probability of occurrence of a 1 in 10 years event and the exposure to a gable roof.

\section{Snow load}

The static snow loads and their distribution were calculated by applying ÖNORM EN 1991-1-3 and the national specifications ÖNORM B 1991-1-3 (ON 2005b, 2006b). In dependence on the location above sea level and a specific meteorological zonation, the characteristic snow load was calculated with $s_{k}=2.10 \mathrm{kN} / \mathrm{m}^{2}$, representing the averaged local snow conditions in Austria.
2, $d$ building width parallel to the flow direction, $b$ building width normal to the flow direction. The gray arrow indicates the flow direction, a lateral view, b top view

The snow load on a gable roof was calculated by using Eq. 1, the design coefficient $\mu_{A}$ is dependent on the inclination $\alpha$ of the roof and was averaged with 0.8 for an inclination of $\alpha=30^{\circ}$. Hence, the resulting snow load $s_{A}$ equals $1.68 \mathrm{kN} / \mathrm{m}^{2}$, while in a second set of calculations, the design load DL1 was modified to include the effect of snowdrift as shown in Fig. 5. Design load DL2 assumed a snow drift on the valley side of the roof, and for DL3 snow drift effects on the hillside were taken into account. The resulting snow loads were modified accordingly.

$s_{A}=\mu_{A} \times s_{k}\left[\mathrm{kN} / \mathrm{m}^{2}\right]$

Additional loads resulting from natural hazard impact

The building envelope is affected by additional forces resulting from the impact of natural hazard processes such as fluvial sediment transport and snow avalanches. The general impact pressure of flowing masses on obstacles is based on hydrodynamic approaches following Eq. 2. Thereby, forces resulting from the impact are considered as stationary and therefore time-independent, and flow velocities are considered as being constant over the flow depth.
Table 1 Coefficients $\left(C_{p e, 10}\right)$ for the assignment of wind storm and powder avalanches loads impacting gable roofs according to $\mathrm{ON}(2006 \mathrm{a}, \mathrm{b})$

$h_{1}, h_{2}, b$ and $d$ refer to the building dimensions outlined in Fig. 4

\begin{tabular}{|c|c|c|c|c|}
\hline & \multicolumn{2}{|c|}{$\begin{array}{l}\text { Impact windstorm } \\
\left(\mathrm{h}_{1} / \mathrm{b}=0.8 \text { and } \mathrm{d} / \mathrm{b}=0.7\right)\end{array}$} & \multicolumn{2}{|c|}{$\begin{array}{l}\text { Impact powder avalanche } \\
\left(\mathrm{h}_{2} / \mathrm{b}=0.5 \text { and } \mathrm{d} / \mathrm{b}=0.7\right)\end{array}$} \\
\hline & Min & Max & Min & Max \\
\hline \multicolumn{5}{|l|}{ Wall area } \\
\hline A & -1.04 & & -1.0 & \\
\hline B & -0.74 & & -0.7 & \\
\hline $\mathrm{D}$ & 0.8 & & 0.8 & \\
\hline $\mathrm{E}$ & -0.37 & & -0.35 & \\
\hline \multicolumn{5}{|c|}{ Roof area } \\
\hline$F=G$ & -0.5 & 0.7 & -0.5 & 0.7 \\
\hline $\mathrm{H}$ & -0.3 & 0.7 & -0.3 & 0.7 \\
\hline I & -0.4 & 0 & -0.4 & 0 \\
\hline $\mathrm{J}$ & -0.5 & 0 & -0.5 & 0 \\
\hline
\end{tabular}




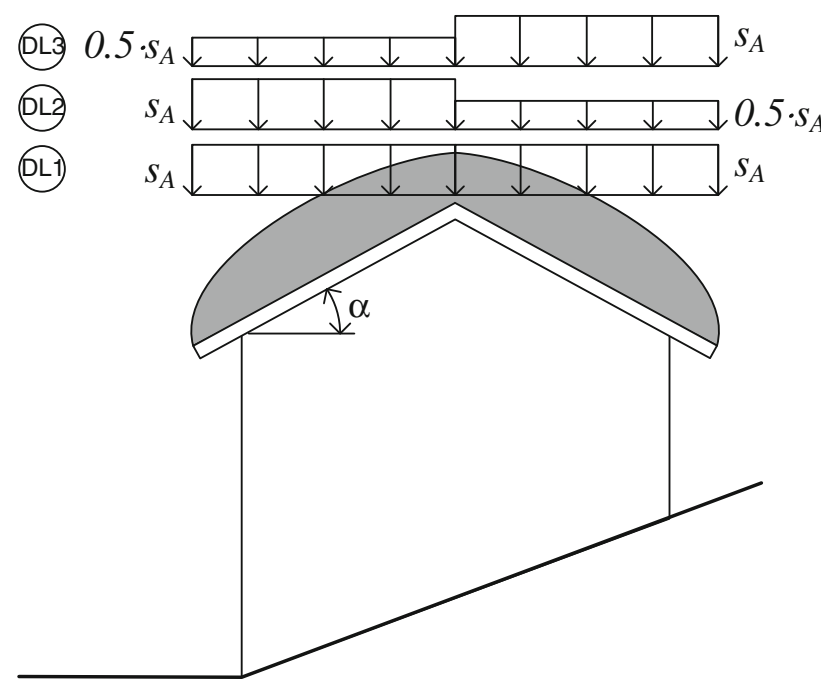

Fig. 5 Structural system for snow impacting a building, $D L 1$ load factor $1, D L 2$ load factor $2, D L 3$ load factor $3, s_{A}$ snow load, $\alpha$ inclination of the roof

The impact of transported solids, such as woody debris and larger boulders, is considered separately due to the higher pressure which affects the building envelope locally in selected areas.

$p=C \times 0.5 \times \rho \times v^{2} \times(\sin \alpha)^{2}\left[\mathrm{kN} / \mathrm{m}^{2}\right]$

where, $\rho$ is the density of the fluid, $v$ is the velocity of the fluid, $C$ is the drag coefficient of the circumfluent obstacle, dependent on the type of process, the rheology of process and the geometry of the obstacle (design coefficient).

The angle $\alpha$ is the inclination between the impacted wall (of the building envelope) and the flow direction of the hazard process. If the impacted wall is directed parallel to the flow path, an angle of $\alpha=20^{\circ}$ is used as an approximation instead to mirror the occurring forces accordingly. The impact pressure is directed normal to the impacted walls.

If any flowing masses impact an obstacle the additional resistance will increase the flow depth due the backwater effects. This increase in flow depth is approximated by Eq. 3 for fluvial sediment transport and Eq. 4 for snow avalanches.

$h_{\text {Stau }}=\frac{v_{f l}^{2}}{2 \times g}[\mathrm{~m}]$

$h_{\text {Stau }}=\frac{v_{L}^{2}}{2 \times g \times \lambda}[\mathrm{m}]$

where, $v_{f}$ is the velocity of the flowing mass, $v_{L}$ is the velocity of the snow mass, $g$ is the acceleration of gravity, $\lambda$ is the stowage height coefficient (dependent from flow characteristics of the fluid; dimensionless)

If areas are impacted with an angle $\alpha \neq 90^{\circ}$, a friction tension (shear stress) $q_{f, R}$ (fluvial sediment transport) and $S_{L, R}$ (snow avalanches) additionally to the normal force has to be considered (Eq. 5 for fluvial sediment transport and Eq. 6 for snow avalanches). Thereby, the friction coefficient $\mu$ is dependent on the roughness of the impacted wall.

$q_{f l, R}=\rho_{f l} \times g \times h_{f l} \times \tan \beta\left[\mathrm{kN} / \mathrm{m}^{2}\right]$

where, $\rho_{f l}$ is the density of fluid, $g$ is the acceleration of gravity, $h_{f}$ is the flow depth, $\tan \beta$ is the inclination between the impacted wall (of the building envelope) and the flow direction of the hazard process.

$s_{L, R}=\mu \times s_{L F, \alpha}\left[\mathrm{kN} / \mathrm{m}^{2}\right]$

where, $\mu$ is the frictional loss coefficient, $s_{L F, \alpha}$ to be calculated according to Table 2 .

In Table 2, the overall equations used to calculate the impact pressure of fluvial sediment transport and snow avalanches are provided.

\section{Fluvial sediment transport}

Design loads were based on the assumption that a building adjacent to a torrent is affected by flooding with moderate sediment load, and parameters characterizing the fluvial sediment transport are shown in Table 3.

Table 2 Equations used to calculate the impact pressure of fluvial sediment transport and snow avalanches

\begin{tabular}{llll}
\hline Process & Pressure & Variable & \\
\hline Fluvial process & $p_{f l, d y n}=c_{d} \times 0.5 \times \rho_{f l} \times v^{2} \times(\sin \alpha)^{2}$ & $c_{d}$ & Drag coefficient \\
& $p_{f l, s t a t}=\rho_{f l} \times g \times h_{f l}$ & & \\
& $p_{f l}=p_{f l, s t a t}+p_{f l, d y n}$ & & \\
Powder avalanche & $s_{L S}=c_{p} \times c_{L S}(z) \times 0.5 \times \rho_{L S} \times v_{L S}^{2}=c_{p} \times s_{L S}(z)$ & $c_{L S}(z)$ & Powder avalanche coefficient (Issler 1999) \\
& & $c_{p}$ & Pressure coefficient \\
Dense flow avalanche ${ }^{\mathrm{a}}$ & $s_{L F, \alpha}=c_{d} \times 0.5 \times \rho_{L F} \times v_{L F}^{2} \times(\sin \alpha)^{2}$ & $c_{d}$ & Drag coefficient
\end{tabular}

a Surfaces are impacted in normal direction 
Table 3 Parameters necessary to calculate the impacts resulting from fluvial sediment transport

\begin{tabular}{lll}
\hline Parameter & Value & Source \\
\hline Flow height $\left(h_{f l}\right)$ & $1.0 \mathrm{~m}$ & Assumption \\
Density $\left(\rho_{f}\right)$ & $1,300 \mathrm{~kg} / \mathrm{m}^{3}$ & (Bergmeister et al. 2008; ONR 2009) \\
Velocity $\left(v_{f}\right)$ & $4.0 \mathrm{~m} / \mathrm{s}$ & (ONR 2009) \\
Design coefficient (rectangle) $\left(c_{d}\right)$ & 1.50 & (Egli 1999) \\
Design coefficient (splitting wedge) $\left(c_{d}\right)$ & 1.25 & (Egli 1999) \\
\hline
\end{tabular}

Fluvial sediment transport results in a pressure on the luvward side $\left(p_{f}\right)$. The impact pressure on the walls parallel to the flow direction $(K)$ were calculated as an area being impacted with an angle of $20^{\circ}\left(p_{f 120, K}\right)$, and an additional frictional tension $p_{f, K}$ is assumed at these walls (Fig. 6). Additionally, woody material transport was assumed at the exposed building wall $\left(q_{e f}\right)$, and was considered with a maximum pressure within an area of $0.5 \mathrm{~m} \times 0.5 \mathrm{~m}$.

The design load resulting from DL 1 is presented in Fig. 6; and the resulting impact pressures where calculated by applying Eqs. 3 and 5 based on the equations provided in Table 2 and the parameters shown in Table 3, and are presented in Table 4.

\section{Snow avalanche}

Design loads were based on the assumption of a mixedtype snow avalanche hitting an obstacle, composed from a (dense) flow part and a superimposed powder part (Bründl et al. 2010). The parameters necessary for the calculation of design load are summarized in Table 5.

The flow part of an avalanche causes a pressure on the luvward side of the obstacle $\left(s_{L F}\right)$. The impact pressure on the walls parallel to the flow direction $(K)$ were calculated as an area being impacted with an angle of $20^{\circ}\left(s_{L F 2 O, K}\right)$, and an additional frictional tension $s_{L R, K}$ is assumed at these walls. Additionally, potentially transported material (e.g., boulders, logs) was assumed at the process ward building wall $\left(q_{e L F}\right)$, and was considered with a maximum pressure within an area of $0.5 \mathrm{~m} \times 0.5 \mathrm{~m}$ (Fig. 7).
The design loads resulting from DL1 (dense flow part) and DL2 (powder part) are presented in Fig. 7; and the resulting impact pressures were calculated by applying Eqs. 4 and 6 based on the equations shown in Table 2 and the parameters shown in Table 5, and are presented in Table 6. Loads incurring in the roof area $\left(s_{L S, G}-s_{L S, J}\right)$ were calculated by applying values from Table 2 following principles outlined in ÖNORM EN 1991-1-4 (ON 2005a).

\section{Prototype}

Taking into account the loads on the building envelope outlined in the previous section, a prototype for a contemporary reinforced building was developed. This prototype represents a typical alpine residential building in the European Alps. Due to topographical constraints, residential buildings in mountain areas of Europe are commonly constructed in a hillside situation. The characteristic building includes a basement as well as first floor (ground floor) and second floor (upper floor). The average effective floor space equals $70 \mathrm{~m}^{2}$, which amounts to approximately $210 \mathrm{~m}^{2}$ in total (see Fig. 8). Supporting walls consist of masonry while the baseplate and the ceilings are constructed from reinforced concrete, respectively. Timber is used for the roof truss, as well as the frame connectors for windows and doors. The roof truss is covered by copper sheet; the roof area is of projecting type in order to better protect the outside walls. Due to the hillside situation, the basement serves usually
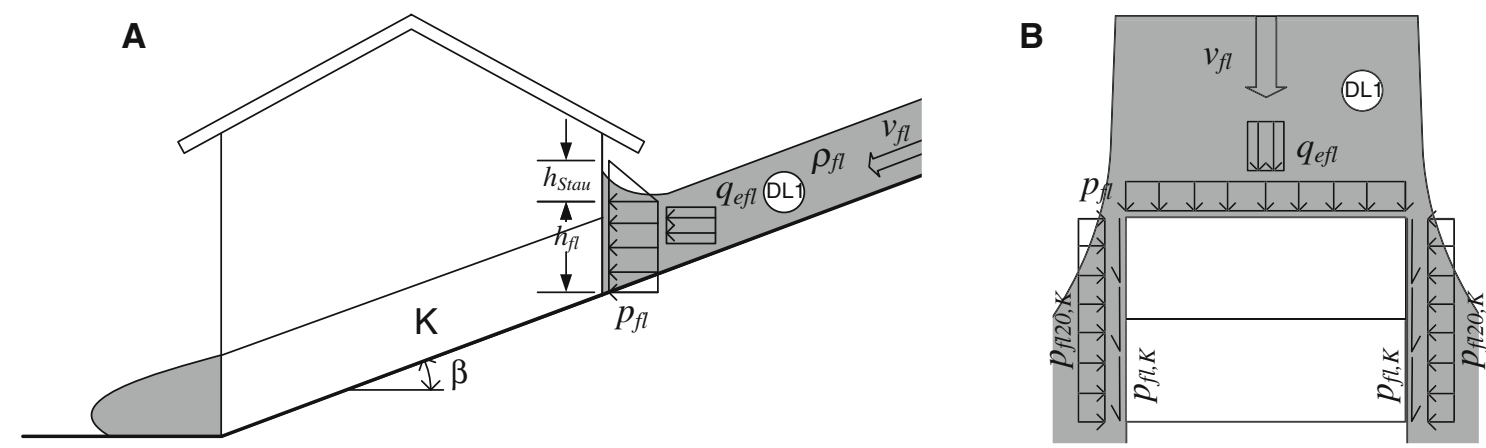

Fig. 6 Structural system for fluvial sediment transport impacting a building, $D L 1$ load factor $1, p_{f t}$ pressure on the luvward side, $p_{f t, K}$ frictional tension, $p_{f 20, K}$ frictional tension assuming an impact angle of $20^{\circ}, q_{e f t}$ impact pressure due to woody material transport, $v_{f l}$ flow velocity, $\rho$ density of the fluid, $h_{f t}$ flow height, $h_{\text {Stau }}$ backwater effects due to Eq. 3, a lateral view, b top view 
Table 4 Impact pressures resulting from the impact of fluvial sediment transport on a building

Loads on the walls

\begin{tabular}{llllllll}
\hline$p_{f l} \quad 15.6$ & $p_{f l, 20, K}$ & 1.82 & $q_{\text {efl }}$ & 288 & $p_{f l, K}$ & 4.64 \\
$h_{\text {Stau }}=$ & $0.8 \mathrm{~m}$
\end{tabular}

Values are provided in $\mathrm{kN} / \mathrm{m}^{2}$ as a quasi-first floor towards the valley. At the hillside, light wells are installed to allow for a utilization of the basement.

The possible loads due to hazardous events outlined in the previous section will result in several shortcomings of these typical residential buildings with respect to the design of their envelope:
Table 5 Parameters necessary for the calculation of design loads for mixed-type snow avalanches

\begin{tabular}{|c|c|c|c|}
\hline $\begin{array}{l}\text { Avalanche } \\
\text { type }\end{array}$ & Parameter & Value & Source \\
\hline \multirow{8}{*}{$\begin{array}{l}\text { Dense flow } \\
\text { part }\end{array}$} & Flow depth $\left(h_{L F}\right)$ & $1.5 \mathrm{~m}$ & Assumption \\
\hline & Snowpack depth $\left(h_{A}\right)$ & $0.5 \mathrm{~m}$ & Assumption \\
\hline & Density $\left(\rho_{L F}\right)$ & $300 \mathrm{~kg} / \mathrm{m}^{3}$ & $\begin{array}{l}\text { (ASTRA 2007; ONR } \\
\text { 2007) }\end{array}$ \\
\hline & Velocity $\left(v_{L F}\right)$ & $20 \mathrm{~m} / \mathrm{s}$ & $\begin{array}{l}\text { (Bozhinskiy and } \\
\text { Losev 1998) }\end{array}$ \\
\hline & Drag coefficient, rectangle $\left(c_{d}\right)$ & 2.0 & (Egli 1999) \\
\hline & Drag coefficient, splitting wedge $\left(c_{d}\right)$ & 1.5 & (Egli 1999) \\
\hline & $\begin{array}{l}\text { Dimensionless coefficient due to flow } \\
\text { characteristics }(\lambda)\end{array}$ & 1.5 & (Egli 1999) \\
\hline & Friction coefficient $(q)$ & 0.3 & (Egli 1999) \\
\hline \multirow[t]{4}{*}{ Powder part } & Flow depth $\left(h_{L S}\right)$ & $\begin{array}{l}\text { Exceeding obstacle } \\
\text { height }\end{array}$ & Assumption \\
\hline & Density $\left(\rho_{L S}\right)$ & $20 \mathrm{~kg} / \mathrm{m}^{3}$ & $\begin{array}{l}\text { (ON 2006c; ONR } \\
\text { 2007) }\end{array}$ \\
\hline & Velocity $\left(v_{L S}\right)$ & $40 \mathrm{~m} / \mathrm{s}$ & $\begin{array}{l}\text { (Bozhinskiy and } \\
\text { Losev 1998) }\end{array}$ \\
\hline & Powder avalanche coefficient $\left(c_{L S}(z)\right)$ & 2 & (Issler 1999) \\
\hline
\end{tabular}

A

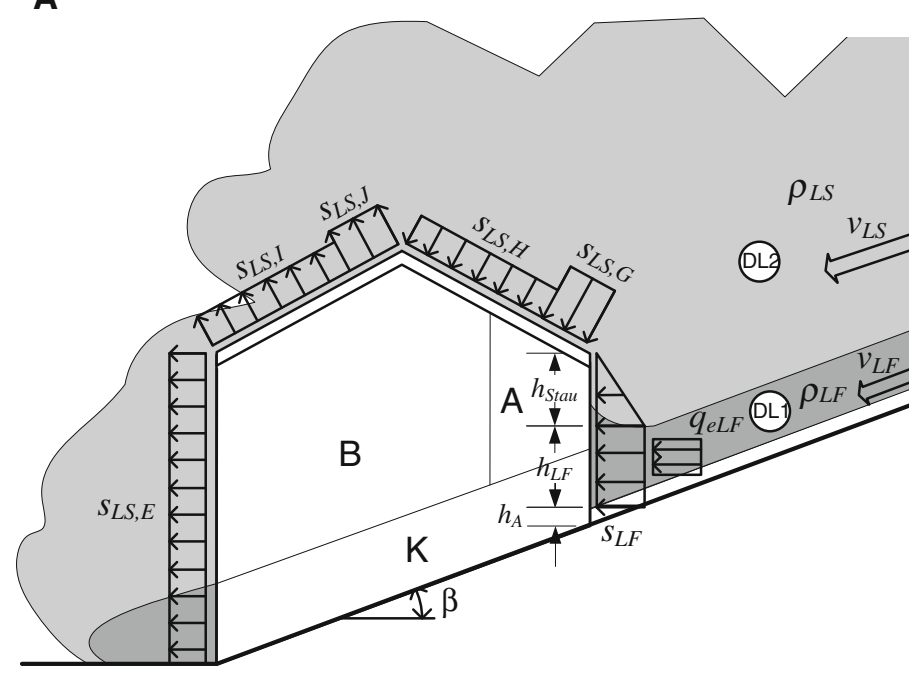

B

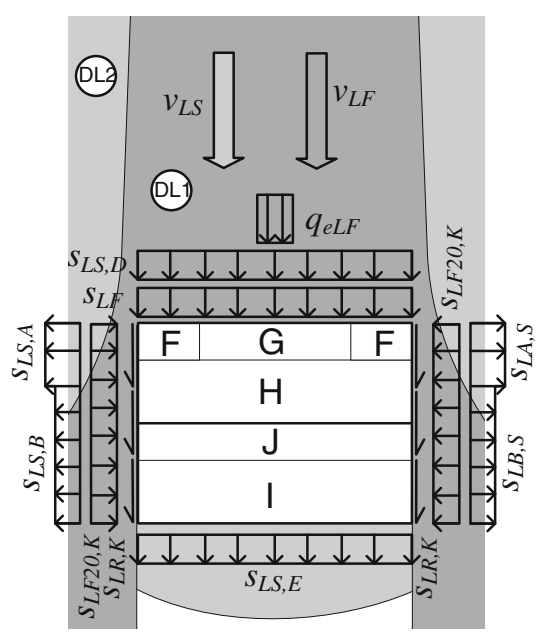

Fig. 7 Structural system for snow avalanches impacting a building, $D L 1$ load factor 1 (flow part) and $D L 2$ load factor 2 (powder part), flow part: $S_{L F}$ pressure on the luvward side, $S_{L R, K}$ frictional tension, $S_{L F 20, K}$ frictional tension assuming an impact angle of $20^{\circ}, q_{e L F}$ impact pressure due to woody material transport, $v_{L F}$ flow velocity,
$\rho_{L F}$ density of the fluid, $h_{L F}$ flow height, $h_{\text {Stau }}$ backwater effects due to Eqn. $4, h_{A}$ height of the initial snow cover, powder part: $S_{L A \ldots J}$ load on the respective section $A \ldots J, v_{L S}$ flow velocity, $\rho_{L S}$ density of the fluid, a lateral view, $\mathbf{b}$ top view 
Table 6 Impact pressures resulting from the impact of a mixed-type avalanche on a building

\begin{tabular}{lllll}
\hline \multicolumn{2}{l}{ Loads on the walls } & \multicolumn{3}{l}{ Loads on the roof } \\
\cline { 3 - 5 } & & & Min & Max \\
\hline$s_{L F}$ & 120 & $s_{L S, F}$ & -16 & 22.4 \\
$s_{L F, 20, K}$ & 14 & $s_{L S, G}$ & -16 & 22.4 \\
$q_{e F}$ & 400 & $s_{L S, H}$ & -9.6 & 22.4 \\
$s_{L R, K}$ & 4.2 & $s_{L S, I}$ & -12.8 & 0 \\
$s_{L S(z)}$ & 32 & $s_{L S, J}$ & -16 & 0 \\
$s_{L S, A}$ & -32 & & & \\
$s_{L S, B}$ & -22.4 & & & \\
$s_{L S, D}$ & 25.6 & & & \\
$s_{L S, E}$ & -11.2 & & & \\
$h_{S t a u}=13 \mathrm{~m}$ & & & & \\
\hline
\end{tabular}

Values are provided in $\mathrm{kN} / \mathrm{m}^{2}$

1. Due to the process characteristics of fluvial sediment transport and snow avalanches, openings generally weaken the static resistance and stability of any wall. Moreover, they are a probable location for intrusion of material such as debris, water, and snow masses, above all due to the inherent material weakness of doors and windows.

2. If the material has been deposited in the interior of the building, an additional static load on ceilings and walls will occur.

3. With respect to torrent processes erosion initiated by surface runoff alongside the walls and as a result from possible shifts in the channel bed may lead to a scouring of the baseplate.

4. An overstrain of the sewage system associated with extraordinary flood discharge may cause back water effects in the sewage pipes of the building and, as a result, cause flooding from inside.

5. With respect to snow avalanches, a projecting roof is considered susceptible to damage due to the occurring pressure gust and suction effects which result from the velocity of the powder part of the avalanche.

As a consequence, a necessary mitigation concept has to be developed taking into account these shortcomings. This concept, referred to as local structural protection, has necessarily to be adjusted to the appearing loads.

Mitigation by local structural protection measures can be distinguished and classified in various ways, i.e., according to the applicability for protection against the hazard process, the location with respect to the protected object, as well as the type of construction and construction materials used (Holub and Hübl 2008). Furthermore, local structural protection can be performed either in terms of a structural reinforcement of an existing building envelope, or in terms of a construction design comprehensively adapted to possible loads of a new construction. Thereby, constructive measures can either be physically connected to the building envelope (e.g., a reinforced window shutter), or the envelope as a whole could be adopted (e.g., by removing any window openings at the exposed building side). Furthermore, a construction directly adjacent to the building envelope could be performed (e.g., an avalanche splitting wedge not connected to the building envelope). However, the overall aim is to develop a cost-efficient and protection-effective solution (Holub and Fuchs 2008) that simultaneously fulfils the requirements of a formal aesthetic standard.

\section{Structural reinforcement of the building}

The structural reinforcement of any building in terms of increased protection against the impact of natural hazard processes (i.e., fluvial sediment transport and snow avalanches) can be achieved by different constructive approaches. In this section, possible adaptations will be presented with respect to reinforcement of the foundation, the structural levels (first and second floor), the roof construction, as well as with respect to additional design elements such as building openings, or mobile protection elements (see Table 7 and Fig. 9).

A major protective effect regarding possible settlements of the entire building, which may occur due to erosion originating from torrent processes, includes the construction of a base plate instead of a strip foundation; a measure that is obviously suitable to increase the overall stability.

Furthermore, the basement should be waterproofed by a sealed type of construction obtained by the use of waterproofed concrete, including the sealing of penetration such as pipes and infrastructure facilities. Light shafts implemented should exceed the expected possible flood level in order to prevent the intrusion of liquids and solids into the interior. Moreover, a backflow flap installed in the sewage system effectively prevents the effects of possible capacity overload of the drainage.

The first floor is particularly susceptible to any type of external impact resulting from torrent processes and snow avalanches, i.e., the additional dynamic as well as static pressure towards the outer walls caused by the medium, and pressure peaks originating from transported solid particles (woody debris, boulders). Therefore, process-side outer walls should be either retrofitted in case of existing structures (e.g., by an additional concrete shell) or constructed from reinforced concrete instead of brick masonry in case of a new construction.

With respect to the roof construction, eaves should be avoided to increase the resistance of the structure against 
Fig. 8 Prototype building representing a typical alpine residential building

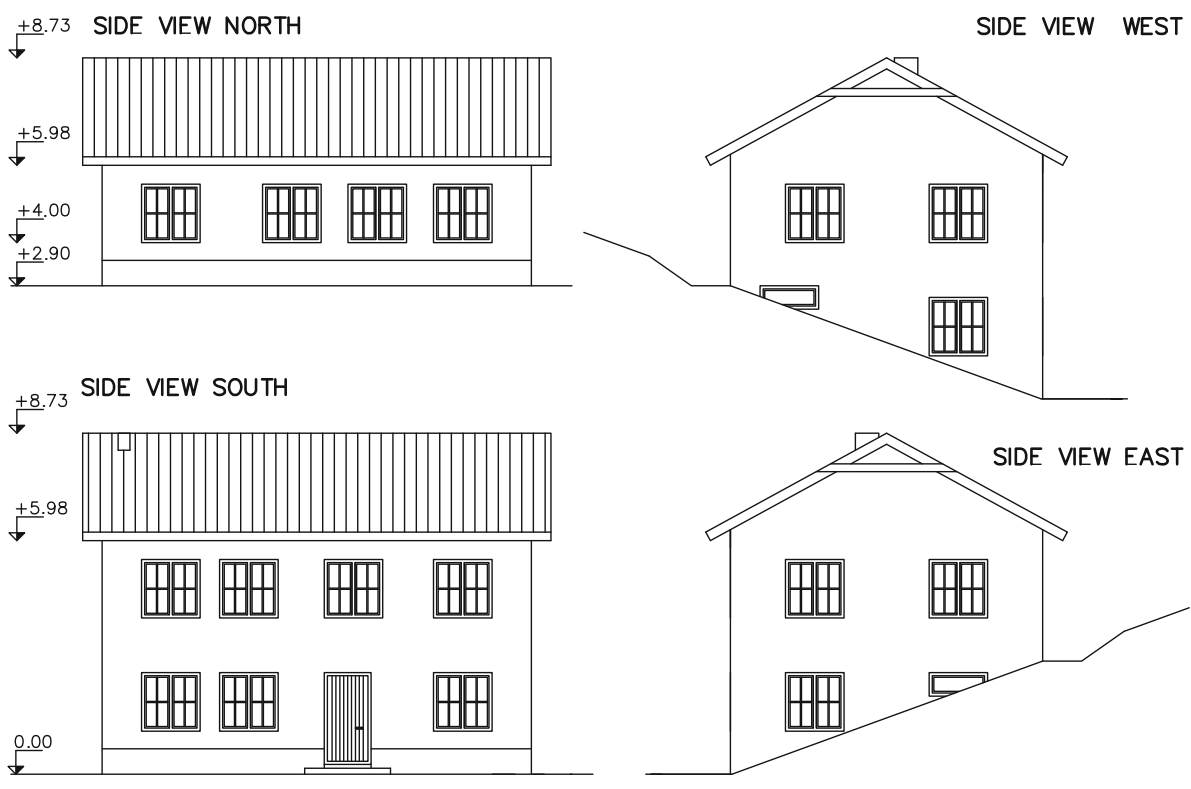

GROUND VIEW 2nd FLOOR
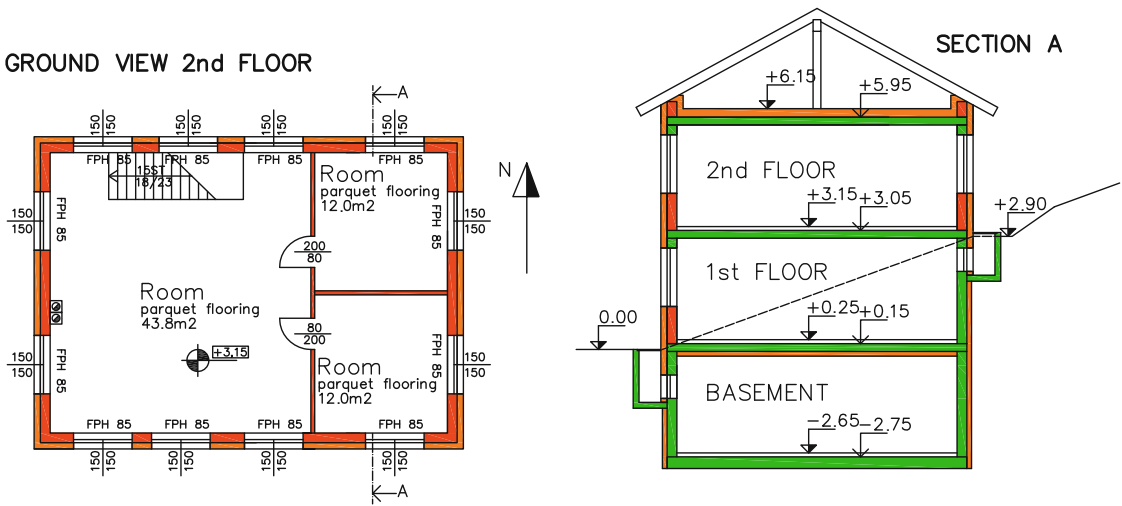

GROUND VIEW 1st FLOOR

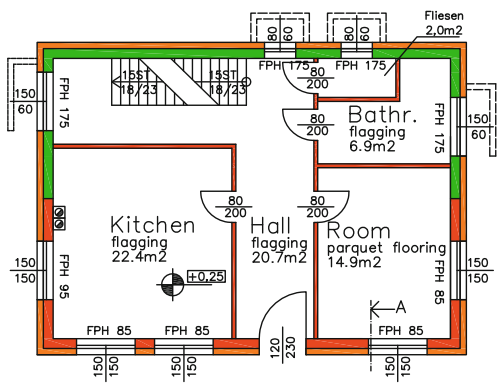

GROUND VIEW BASEMENT
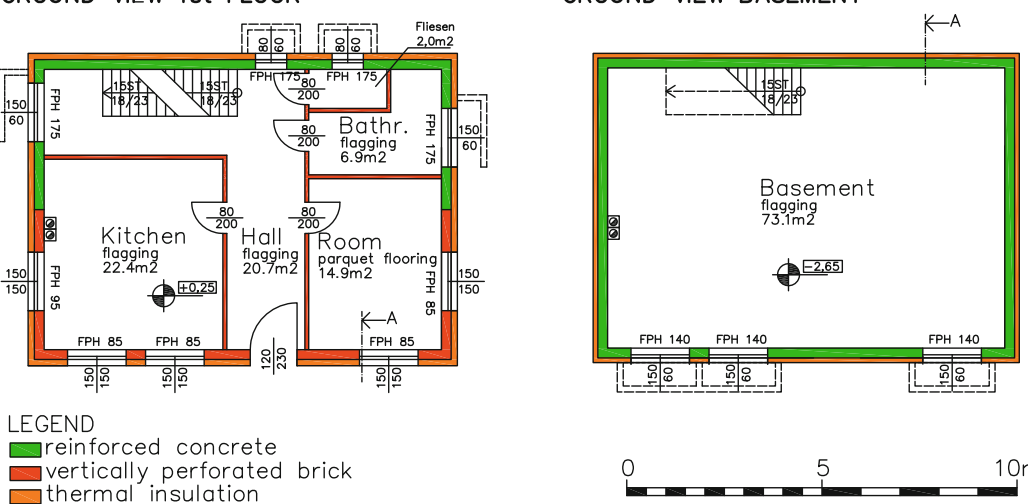

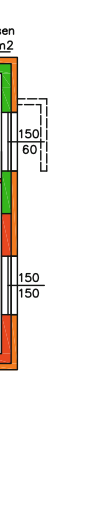

pull resulting from avalanche processes. Furthermore, an overall strengthening is recommended to resist heavy snow loads; however, this is regularly prescribed in the local building codes.

As an overarching framework, any building openings should be avoided on the process-oriented (impacted) building walls. If this is not possible due to architectural or esthetical constraints, the building openings have to be reduced in number and size, and any openings at ground surface level should be eliminated. If necessary, specially reinforced multilayer window glass, window frames and fittings are available to protect against the considerable impact pressure of hazard processes, i.e., snow avalanches. A combination with window shutters mounted at the exterior of the wall instead within the window frame complements these suggestions.

Additionally, mobile elements may protect building openings from the intrusion of material; however, such 
Table 7 Possible local structural mitigation measures for a reinforcement of the building

\begin{tabular}{|c|c|c|c|c|c|}
\hline \multirow{2}{*}{$\begin{array}{l}\text { Local structural } \\
\text { protection measure }\end{array}$} & \multirow[t]{2}{*}{ Type of measure } & \multicolumn{2}{|c|}{ Effective for } & \multicolumn{2}{|c|}{ Suitable for } \\
\hline & & Avalanche & Flood & Upgrade & $\begin{array}{l}\text { New } \\
\text { building }\end{array}$ \\
\hline Foundation & Base plate foundation & $(\mathrm{x})$ & $\mathrm{x}$ & - & $\mathrm{x}$ \\
\hline \multirow[t]{3}{*}{ Basement } & Waterproofed concrete & - & $\mathrm{x}$ & - & $\mathrm{x}$ \\
\hline & $\begin{array}{l}\text { Enhancement (raising) of light shafts above flood level (flow depth) and sealing } \\
\text { of all wall penetrations }\end{array}$ & $(\mathrm{x})$ & $\mathrm{x}$ & $\mathrm{x}$ & $\mathrm{x}$ \\
\hline & Backflow flaps in sewage pipes & - & $\mathrm{x}$ & (x) & $\mathrm{x}$ \\
\hline $\begin{array}{l}\text { First (and second) } \\
\text { floor }\end{array}$ & Reinforcement of the supporting structure (walls, ceilings ...) & $\mathrm{x}$ & $\mathrm{x}$ & $(\mathrm{x})$ & $\mathrm{x}$ \\
\hline Roof & Reinforcement of the roof, avoidance of eaves & $\mathrm{x}$ & - & $(\mathrm{x})$ & $\mathrm{x}$ \\
\hline \multirow[t]{2}{*}{ Building openings } & $\begin{array}{l}\text { Decrease of the amount and area of windows and implementation of avalanche } \\
\text { safe windows and/or heavy shutters }\end{array}$ & $\mathrm{x}$ & $(\mathrm{x})$ & $\mathrm{x}$ & $\mathrm{x}$ \\
\hline & $\begin{array}{l}\text { Implementation of temporarily preventive measures such as mobile stop logs at } \\
\text { (at least) the openings exposed towards processes (windows, doors, gates) }\end{array}$ & (x) & $\mathrm{x}$ & $\mathrm{x}$ & $\mathrm{x}$ \\
\hline
\end{tabular}

The effectiveness is indicated by $\mathrm{x}=$ very effective $(\mathrm{x})=$ effective and $-=$ not effective and the suitability for the upgrading of existing buildings is indicated similarly

elements necessarily have to be stored nearby an endangered object in order to guarantee availability during an event.

Constructive measures adjacent to the building

Apart from a structural reinforcement, the protection of any building exposed to natural hazards can be supplemented by constructive measures adjacent to these elements at risk. Besides, such measures are also appropriate to exposed constructions where either a structural reinforcement is not possible (e.g., due to financial limitations or restrictions due to monument conservation) or only possible with extraordinary efforts. In this section, a respective measure is presented in detail by taking avalanche splitting wedges and combinations between deflection dams and walls as an example (see Table 8).

A splitting wedge has a triangular shape and is generally located at the process-oriented side of a building exposed. While the vertex is directed towards the run-out area, the sides are designed in such a way that the gravitational mass movement directed downslope (e.g., a snow avalanche) is split and deflected into an area which is to be kept free of elements at risk. As a result, damage to the exposed building will be prevented. The main criterion for an effective operation of such a structure is a stable anchoring and an adequate height of the construction in order to avoid an overtopping. Furthermore, the width of a splitting wedge has to be dimensioned large enough in order to avoid any erosional as well as shearing forces to the side walls of the building to be protected. Splitting wedges are considerable effective in deflecting dense-flow avalanches and are frequently designed as a combination of heavy rip raps and earth-filled dams. As an alternative, reinforced concrete may be used for construction, while is such cases splitting wedges may also be constructed in direct connection to the exposed object (Fig. 10).

A deflection wall is designed following the same principles of protection, and is repeatedly used to protect an entire building ensemble from the impact of mediummagnitude events (Fig. 11). However, since the overall height is occasionally smaller than the height of a splitting wedge, the endangered objects may not entirely be protected and a residual exposure may remain.

\section{Expenses necessary for local structural protection}

Within this section, a prototype of residential building adapted to mountain hazard processes is presented based on the design needs outlined above. This prototype is based on the modern residential building typical for the European Alps and is equipped with various constructional elements which are able to resist the impact forces of hazardous events, i.e., fluvial sediment transport, and snow avalanches. The amount of construction costs are opposed to the additional expenditures necessary for an adapted design. The price basis is related to the average standard construction prices in Austria, which equals approximately the price indices in European mountain regions. The sets of calculation are based on net prices and neglected the sales tax; therefore, the results are in principle applicable to other countries with different taxation systems. A comprehensive overview on absolute prices used for the sets of calculation is provided in the online supplementary material of this article. ${ }^{1}$

\footnotetext{
$\overline{1}$ A detailed calculation is provided in the supplementary online material.
} 
Fig. 9 Prototype building representing a typical reinforced alpine residential building



GROUND VIEW 2nd FLOOR
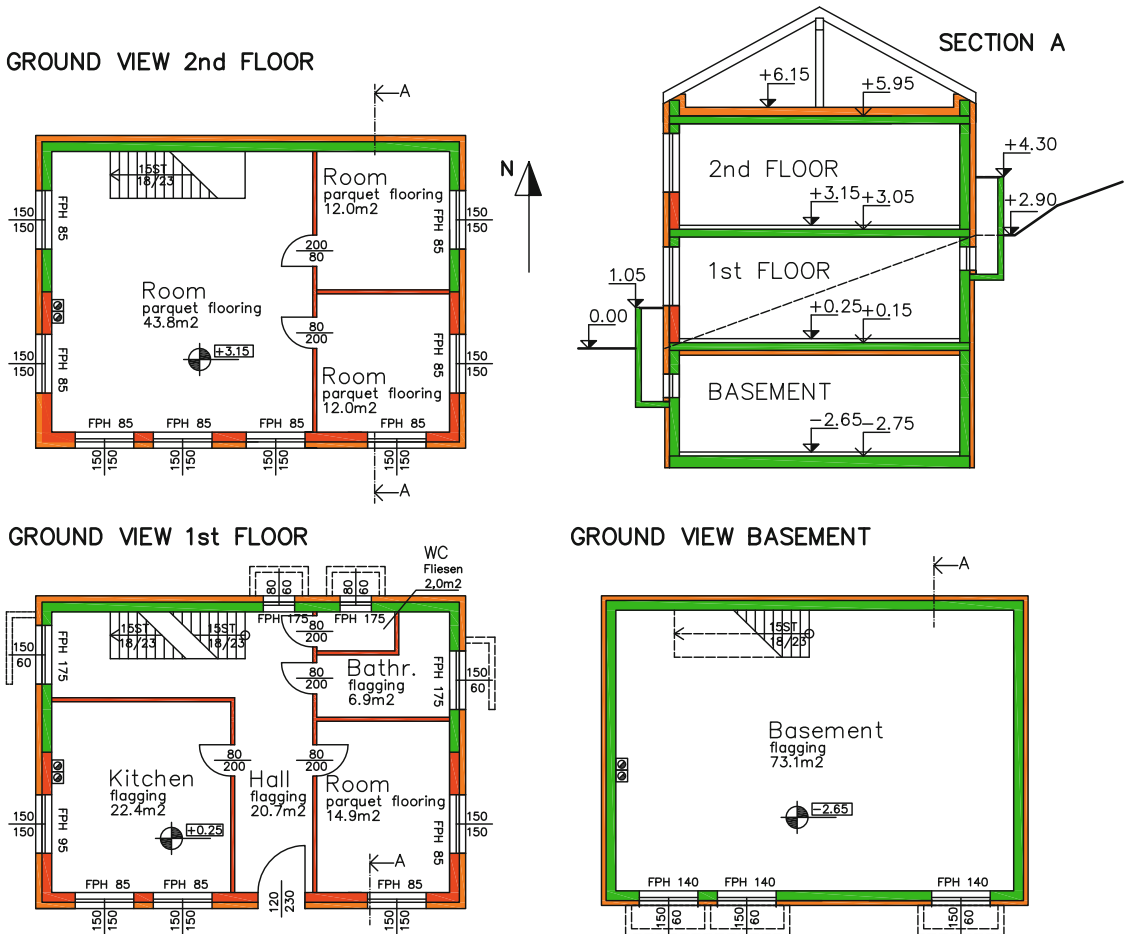

GROUND VIEW BASEMENT

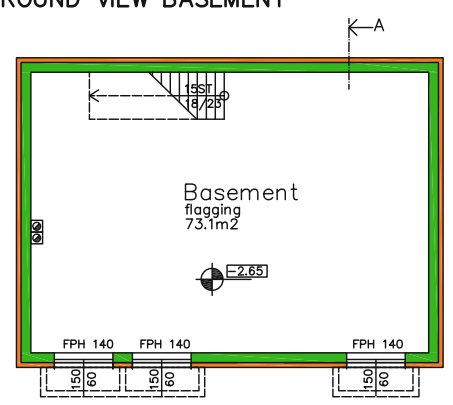

LEGEND

reinforced concrete

$\square$ vertically perforated brick

$\square$ thermal insulation

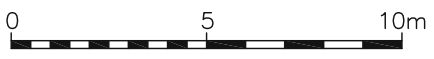

Table 8 Possible local structural mitigation measures adjacent to the building

\begin{tabular}{|c|c|c|c|c|}
\hline \multirow[t]{2}{*}{ Local structural protection measure } & \multicolumn{2}{|c|}{ Effective for } & \multicolumn{2}{|c|}{ Suitable for } \\
\hline & Avalanche & Flood & Upgrade & New building \\
\hline Splitting wedge (hill side exposure) & $\mathrm{x}$ & $(\mathrm{x})$ & $\mathrm{x}$ & $\mathrm{x}$ \\
\hline Deflection walls and dams & $\mathrm{x}$ & (x) & $\mathrm{x}$ & $\mathrm{x}$ \\
\hline
\end{tabular}

The effectiveness is indicated by $\mathrm{x}=$ very effective $(\mathrm{x})=$ effective and $-=$ not effective and the suitability for the upgrading of existing buildings is indicated similarly 


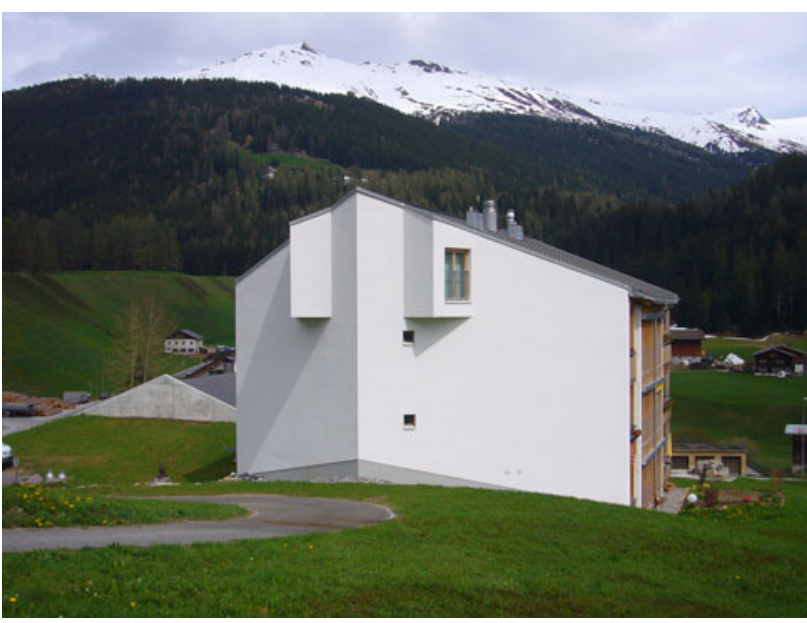

Fig. 10 Splitting wedge directly connected to the exposed object (Davos Frauenkirch, Switzerland)

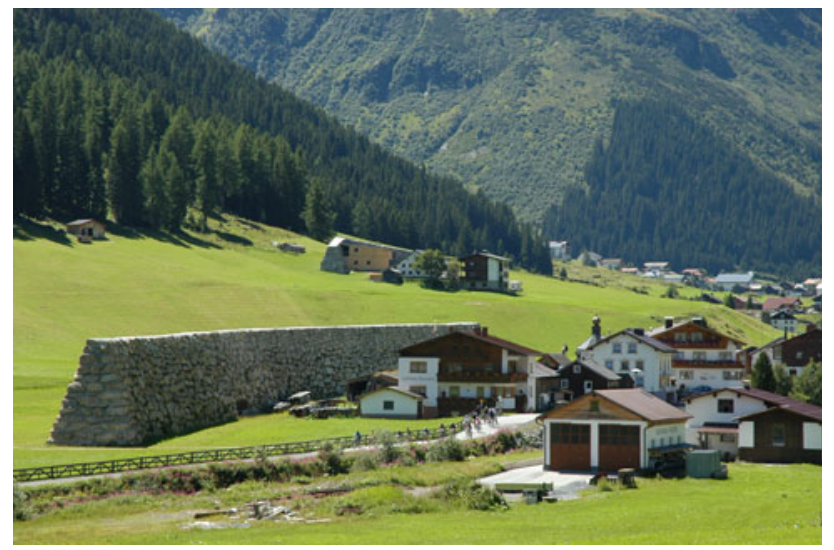

Fig. 11 A deflection wall used to protect an entire building ensemble from the impact of medium-magnitude events (Galtür Tschafein, Austria)

Due to the design loads necessary for the implementation of different local structural protection measures, the average construction costs are above the costs for unprotected buildings. Nevertheless, the ratios differ for individual measures as shown in Table 9. While the additional expenditures for the construction of a structural slab amount to an increase of one-third, and the implementation of avalanche-proof windows result in an increase of twothirds (calculated in terms of the individual costs needed for this respective measure), the reduction of eaves leads to a decrease in construction costs of approximately $16 \%$. In total, the design adaptation of the prototype building under consideration leads to an increase in construction costs of $8 \%$, compared to an unprotected standard building.

In addition, expenses for a necessary splitting wedge were calculated as an example for an enclosing protection structure not physically connected to the building (Fig. 12).
Table 9 Relative increase in construction costs if local structural mitigation is implemented

\begin{tabular}{ll}
\hline Measure & $\begin{array}{l}\text { Increase in construction costs } \\
\text { compared to the respective } \\
\text { standard version [\%] }\end{array}$ \\
\hline $\begin{array}{ll}\text { Reinforcement of the hillside } \\
\text { outer wall }\end{array}$ & +17 \\
$\begin{array}{l}\text { Reinforcement of the structural slab } \\
\text { Reinforcement of the truss }\end{array}$ & +30 \\
$\begin{array}{l}\text { Reduction of eaves (decrease in } \\
\text { roof area) }\end{array}$ & +10 \\
$\begin{array}{l}\text { Avalanche-proof window and } \\
\text { window shutter }\end{array}$ & +67 \\
$\begin{array}{l}\text { Above flood-level light shafts } \\
\text { Total costs of the prototype } \\
\text { reinforced building }\end{array}$ & +23 \\
\hline
\end{tabular}

The calculation included the necessary expenses for concrete including armoring, earth fill, interlocking, and landscaping. The major advantage of a splitting wedge, compared to the conventional local structural protection, is the feasibility of retrofitting to an already existing building without any necessary structural intervention. However, splitting wedges require space, and are therefore not appropriate to every location. The expenditures necessary for a splitting wedge protecting the typical alpine residential building in the European Alps amounted to approximately $€ 72,000$, and are therefore more than four times as much as the total expenditures for local structural protection measures outlined above (35\% of the average construction costs for a standard non-reinforced building in Alpine areas)

\section{Conclusion}

Losses due to natural hazards in European mountain regions were considerably high, even though an increase in absolute figures cannot necessarily be proven for the period since 1950 (Fuchs and Bründl 2005; Fuchs 2009). In parallel, the arising discussion related to possible impacts of climate change on the magnitude and frequency of mountain hazards (Keiler et al. 2010) resulted in a rising scientific debate on the spatiotemporal evolution of elements at risk exposed (e.g., Hufschmid et al. 2005; Fuchs and Bründl 2005; Keiler et al. 2006). As a consequence it may be postulated that risk awareness of the general public and administrative bodies responsible for hazard protection has risen (Commission of the European Communities 2007). Accordingly, the traditional engineering approach of mitigating hazard processes directly in the release areas of individual catchments, e.g., by designing snow rakes in avalanche starting zones and retention barriers in torrent 
Fig. 12 Splitting wedge to protect a building against the impact of snow avalanches
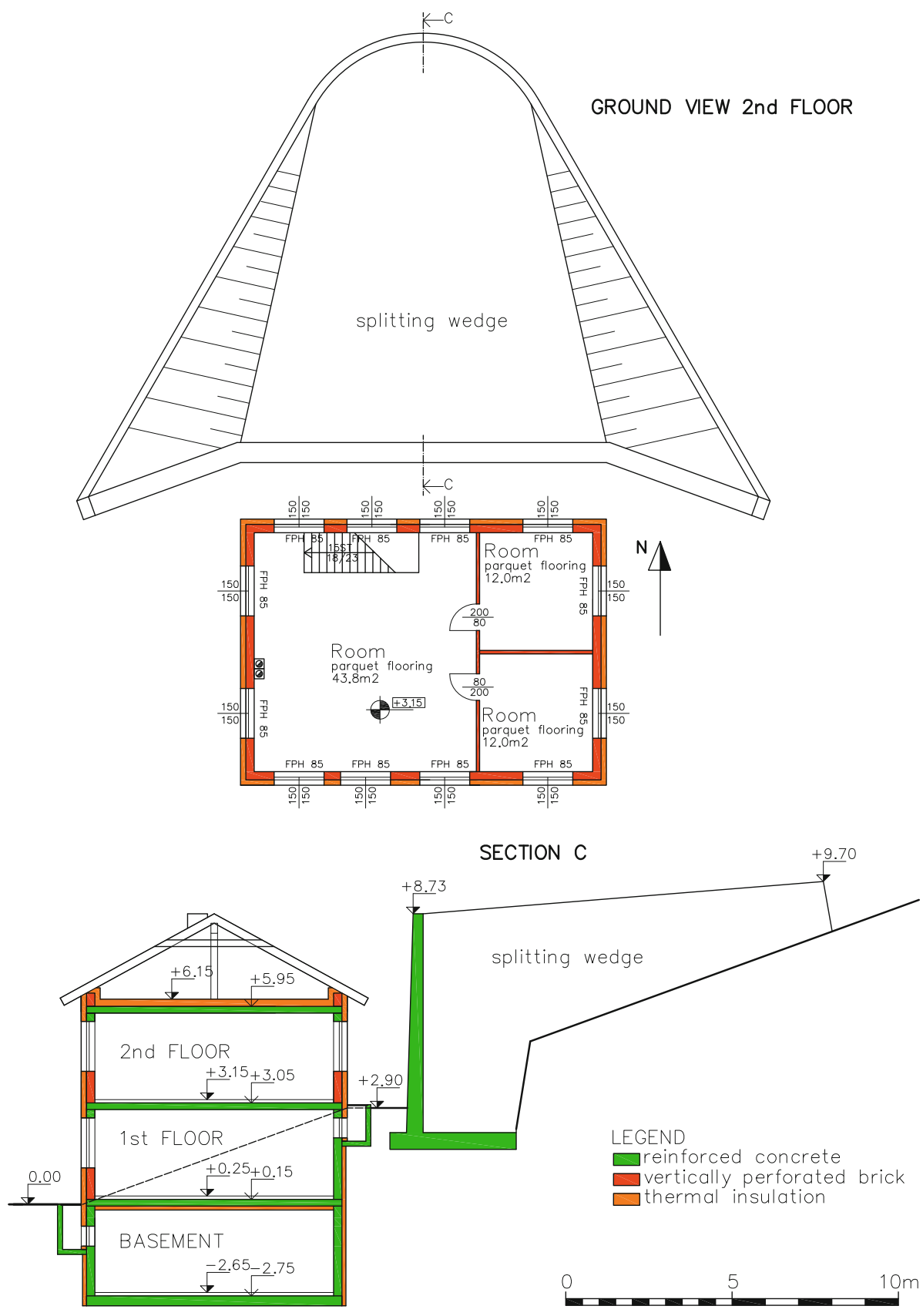

channels, were supplemented by technical structures in the run-out areas, e.g., retention basins (Holub and Fuchs 2009). However, it had been shown that such structures have to be supplemented by passive mitigation concepts such as hazard mapping to reduce an exposure of elements at risk to hazards, a hypothesis that is rooted in very influential earlier works from the practitioners side (e.g., de Crécy 1980; Frutiger 1980; Hackett and Santeford 1980; Hestnes and Lied 1980; Ives and Plam 1980).

Nevertheless, neither conventional structural measures, which influence both, the magnitude and frequency of events, nor passive mitigation concepts can guarantee reliability and complete safety. Therefore, the concept of local structural protection was developed (Egli 1999; Holub and Hübl 2008). This concept has been proven to be very cost-efficient (Holub and Fuchs 2008); above all, since the required expenditures do not necessarily have to taken over by the general public. However, until now only little information was available on the absolute height of investments needed for such measures on the local scale.

Taking these findings as a basis, a prototype of residential building typical for European mountain regions has been presented. Based on possible design loads, this prototype was further equipped with different local structural 
protection measures in order to resist the impact forces of torrent hazards and snow avalanches. The underlying structural modifications were calculated based on information from the Austrian construction industry and the insurance business. As a result, it had been shown that the adaptation of the standard building would result in an increase in construction costs of below $10 \%$.

In absolute number, the increase in construction cost due to the implementation of structural mitigation outlined above amounts to approximately $17,000 €$. If this amount is compared to available data related to direct losses resulting from torrent events and snow avalanches, the savings potential becomes obvious.

The average direct loss per torrent event in Austria equals $170,000 €$, regardless of whether or not one building or a group of buildings suffered damage (in 2010 values, Fuchs 2009); whereas in the years with a considerable number of high-magnitude and low-frequency torrent events, the average loss, of buildings being affected, at the individual building level equals $85,000 €$. In parallel an analysis of losses due to mountain hazards in Eastern Switzerland resulted in an approximated damage of 6,000€ (including the so-called frequency damages resulting from low-magnitude but high-frequency events, Fuchs and Bründl 2005). A similar order of magnitude resulted from an analysis of the 2005 flood events in Austria, where the average damage per claimant was $21,000 €$ on average (Habersack et al. 2004). With respect to snow avalanches, the average loss per claimant amounted to $17,500 €$ in Eastern Switzerland (Fuchs and Bründl 2005).

Comparing the results of our study with such data clearly proved the potential for local structural protection; depending on the data set, an investment of approximately $17,000 €$ is at least able to prevent the effects of lowmagnitude but high-frequency torrent processes (amounting to $8,000 €$ on average, Oberndorfer et al. 2007). With respect to higher-magnitude torrent events, it has to be assumed that at least a considerable portion of the average of $85,000 €$ per damaged building will be prevented, and a respective decrease in loss has to be assumed. With respect to snow avalanches, the investment in local structural protection equals the average loss, which in turn implies that such average loss can be effectively prevented by local structural protection.

Within the overall context of managing natural hazard risk, local structural protection aims at reducing the structural vulnerability of buildings exposed due to a reduction of design loads on the building envelope and due to a prevention of material intrusion through building openings protected. As a result, the resilience towards lowmagnitude and high-frequency events can be enhanced, leading to less economic vulnerability of values at risk exposed (Fuchs 2009). An increased economic resilience, in turn, will put a lesser burden on the public funds necessary, since due to missing overarching insurance systems in Austria the competence of compensating losses that incurred due to natural hazards is allocated on the level of federal states (Holub and Fuchs 2009).

Nevertheless, in some decision contexts one approach to reduce vulnerability is likely to be more effective than another, whereas in other decision contexts a combination may also be appropriate. To give an example, for some buildings located in avalanche run-out areas local structural mitigation (e.g., splitting wedges) to be born by the home owner will be the most promising (and cost-effective) measure to reduce damage, while for other buildings and given another topographic setting the provision of risk sharing mechanisms by obligatory insurance solutions will be most efficient. Often a combination of both will be more successful in reducing the individual and collective risk than only one mitigation alternative (Fuchs et al. 2007c). Effective planning for and response to hazards requires that the vulnerability associated with specific social and decision processes be understood in parallel with understandings of probabilities of occurrence leading to physical vulnerability. Thus, judgements can be made about the appropriate balance between different management options. Apart from such academic concerns, methods to reduce vulnerability to natural hazards may include innovative approaches of risk sharing, as discussed in Holub and Fuchs (2009). Thereby, legislation, loss compensation, and risk transfer are accompanied by the overall aim to increase risk awareness and to implement a sustainable and long-term land use planning.

Acknowledgments The authors kindly would like to acknowledge the support of J. Pichler, master builder and loss assessor, for supporting this study by providing a set of calculation of building costs. This study was funded by the Austrian Science Fund (FWF, L535N10) and further supported by a mobility grant under the umbrella of the Erasmus Munds External Cooperation Window IAMONET-RU provided by the European Commission.

Open Access This article is distributed under the terms of the Creative Commons Attribution Noncommercial License which permits any noncommercial use, distribution, and reproduction in any medium, provided the original author(s) and source are credited.

\section{References}

ASTRA (2007) Einwirkungen infolge Lawinen auf Schutzgalerien, Richtlinie. Bundesamt für Strassen, Bern

Barbolini M, Cappabianca F, Sailer R (2004) Empirical estimate of vulnerability relations for use in snow avalanche risk assessment. In: Brebbia C (ed) Risk Analysis IV. WIT, Southampton, pp 533-542

Barredo J (2007) Major flood disasters in Europe: 1950-2005. Nat Hazards 42:125-148 
Barredo J (2009) Normalised flood losses in Europe: 1970-2006. Nat Hazards Earth Syst Sci 9:91-104

Becker A, Grünewald U (2003) Flood risk in central Europe. Science 300:1099

Bergmeister K et al (2008) Schutzbauwerke gegen Wildbachgefahren. In: Bergmeister K, Wörner J-D (eds) Beton-Kalender 2008. Ernst and Sohn, Berlin, pp 91-289

BMLFUW [Bundesministerium für Land- und Forstwirtschaft, Umwelt und Wasserwirtschaft] (2005) Richtlinien für die Wirtschaftlichkeitsuntersuchung und Priorisierung von Maßnahmen der

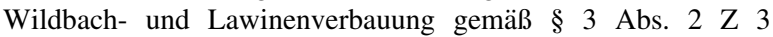
Wasserbautenförderungsgesetz. BMLFUW, Wien

BMLFUW [Bundesministerium für Land- und Forstwirtschaft, Umwelt und Wasserwirtschaft] (2006) Technische Richtlinie für die Wildbach- und Lawinenverbauung gemäß $\S 3$ Abs $1 \mathrm{Z} 1$ und Abs 2 des WBFG 1985 i. d. F. BGBl. Nr. 82/2003 vom 29.8.2003. BMLFUW, Wien

Borter P (1999) Risikoanalyse bei gravitativen Naturgefahren. Umwelt-Materialien, BUWAL Bundesamt für Umwelt, Wald und Landschaft, Bern

Bozhinskiy A, Losev K (1998) The fundamentals of avalanche science [Osnovy lavinovedenija]. Mitteilungen des Eidgenössischen Instituts für Schnee- und Lawinenforschung. Eidgenössisches Institut für Schnee- und Lawinenforschung, Davos

Bründl $M$ et al (2010) Review and future challenges in snow avalanche risk analysis. In: Ayala IA, Goudie AS (eds) Geomorphological hazards and disaster prevention. Cambridge University Press, Cambridge, pp 49-61

Christensen J, Christensen O (2003) Climate modeling: severe summertime flooding in Europe. Nature 421:805-806

Commission of the European Communities (2004) Communication from the Commission to the Council, the European Parliament, the European Economic and Social Committee and the Committee of the Regions - Flood risk management - Flood prevention, protection and mitigation. http://eur-lex.europa.eu/ lexuriserv/lexuriserv.do?uri=com:2004:0472:fin:en:pdf. Accessed 06 October 2011

Commission of the European Communities (2007) Directive 2007/60/ EC of the European Parliament and of the Council of 23 October 2007 on the assessment and management of flood risks. http://eurlex.europa.eu/lexuriserv/lexuriserv.do?uri=oj:1:2007:288: 0027:0034:en:pdf. Accessed 06 October 2011

Costa J (1984) Physical geomorphology of debris flows. In: Costa J, Fleisher P (eds) Developments and applications of geomorphology. Springer, Berlin, pp 268-317

Costa J (1988) Rheologic, geomorphic, and sedimentologic differentiation of water floods, hyperconcentrated flows, and debris flow. In: Baker V, Kochel R, Patton P (eds) Flood geomorphology. Wiley, New York, pp 113-122

de Crécy L (1980) Avalanche zoning in France: regulation and technical bases. J Glaciol 26:325-330

Egli T (1999) Richtlinie Objektschutz gegen Naturgefahren. Gebäudeversicherungsanstalt des Kantons, St. Gallen

Embleton-Hamann C (1997) Naturgefahren in Österreich. Ursachen, Verbreitung, Schäden und Schutzmaßnahmen. Mitteilungen der Österreichischen Geographischen Gesellschaft 139:197-230

Etkin D, Haque C, Brooks G (eds) (2003) An assessment of natural hazards and disasters in Canada. Kluwer, Dordrecht

Fell R et al (2008) Guidelines for landslide susceptibility, hazard and risk zoning for land-use planning. Eng Geol 102:85-98

FEMA (Federal Emergency Management Agency) (1998) Repairing your flooded home. FEMA Publications, Washington

Fliri F (1998) Naturchronik von Tirol. Wagner, Innsbruck

Frutiger H (1980) History and actual state of legalization of avalanche zoning in Switzerland. J Glaciol 26:313-330
Fuchs S (2009) Susceptibility versus resilience to mountain hazards in Austria: paradigms of vulnerability revisited. Nat Hazards Earth Syst Sci 9:337-352

Fuchs S, Bründl M (2005) Damage potential and losses resulting from snow avalanches in settlements of the canton of Grisons, Switzerland. Nat Hazards 34:53-69

Fuchs S, Heiss K, Hübl J (2007a) Vulnerability due to torrent events: a case study from Austria. In: Kellerer-Pirklbauer A, Keiler M, Embleton-Hamann C, Stötter J (eds) Geomorphology for the future. Innsbruck University Press, Innsbruck, pp 97-104

Fuchs S, Heiss K, Hübl J (2007b) Towards an empirical vulnerability function for use in debris flow risk assessment. Nat Hazards Earth Syst Sci 7:495-506

Fuchs S, McAlpin MC, Gruber U, Bründl M (2007c) Avalanche hazard mitigation strategies assessed by cost effectiveness analyses and cost benefit analyses: evidence from Davos, Switzerland. Nat Hazards 41:113-129

Fuchs S et al (2008) The application of the risk concept to debris flow hazards. Geomech Tunn 1:120-129

Guha-Sapir D, Below R (2002) Quality and accuracy of disaster data. A comparative analysis of 3 global data sets. working document prepared for the disaster management facility. World Bank, Brussels

Habersack H, Bürgel J, Petraschek A (2004) Analyse der Hochwasserereignisse vom August 2002: FloodRisk, Synthesebericht. BMLFUW: Bundesministerium für Land- und Forstwirtschaft, Umwelt und Wasserwirtschaft, Wien

Hackett S, Santeford H (1980) Avalanche zoning in Alaska, USA. J Glaciol 26:377-392

Haering B, Gsponer G, Koch P (2002) effor2: Konzeptbericht. Wirkungsorientierte Subventionspolitik im Rahmen des Waldgesetzes. Umwelt-Materialien, BUWAL Bundesamt für Umwelt, Wald und Landschaft, Bern

Hestnes E, Lied K (1980) Natural-hazard maps for land-use planning in Norway. J Glaciol 26:331-343

Hilker N, Badoux A, Hegg C (2009) The Swiss flood and landslide damage database 1972-2007. Nat Hazards Earth Syst Sci 9:913-925

Holub M, Fuchs S (2008) Benefits of local structural protection to mitigate torrent-related hazards. In: Brebbia C, Beriatos E (eds) Risk analysis VI. WIT transactions on information and communication technologies 39. WIT, Southampton, pp 401-411

Holub M, Fuchs S (2009) Mitigating mountain hazards in AustriaLegislation, risk transfer, and awareness building. Nat Hazards Earth Syst Sci 9:523-537

Holub M, Hübl J (2008) Local protection against mountain hazards: state of the art and future needs. Nat Hazards Earth Syst Sci 8:81-99

Hufschmid G, Crozier M, Glade T (2005) Evolution of natural risk: research framework and perspectives. Nat Hazards Earth Syst Sci 5:375-387

Issler D (1999) Berücksichtigung der Staublawinen in der Gefahrenkartierung, Neue Berechungsmethoden in der Lawinengefahrenkartierung. Unveröffentlichte Kursunterlagen, Teil IV

Ives J, Plam M (1980) Avalanche-hazard mapping and zoning problems in the Rocky Mountains, with examples from Colorado, USA. J Glaciol 26:363-375

Johnson L, Frew S, Samant L (2005) Planning for the unexpected: land-use development and risk. American Planning Association, Washington

Keiler M et al (2006) Avalanche risk assessment: a multi-temporal approach, results from Galtür, Austria. Nat Hazards Earth Syst Sci 6:637-651

Keiler M, Knight J, Harrison S (2010) Climate change and geomorphological hazards in the eastern European Alps. Philos Trans A Math Phys Eng Sci 368:2461-2479 
Keylock C (1997) Snow avalanches. Prog Phys Geogr 21(4):481-500

Kundzewicz Z et al (2005) Summer floods in Central Europe: climate change track? Nat Hazards 36:165-189

Loucks D, Stedinger J (2007) Thoughts on the economics of floodplain development in the U.S. In: Vasiliev O, van Gelder P, Plate E, Bolgov M (eds) Extreme hydrological events. New concepts for security NATO Science Series IV: earth and environmental sciences. Springer, Dordrecht, pp 3-19

Luzian R (2002) Die österreichische Schadenslawinen-Datenbank. Forschungsanliegen: Aufbau - erste Ergebnisse. Mitteilungen der forstlichen Bundesversuchsanstalt 175, Wien

McClung D, Schaerer P (1993) The avalanche handbook. The Mountaineers, Seattle

Mitchell J (2003) European river floods in a changing world. Risk Anal 23:567-574

Mudelsee M et al (2003) No upward trends in the occurrence of extreme floods in central Europe. Nature 425:166-169

Nöthiger C et al (2002) Indirekte Auswirkungen von Naturgefahren auf den Tourismus - Das Beispiel des Lawinenwinters 1999 in der Schweiz. Geographica Helvetica 57:91-108

O'Keefe P, Westgate K, Wisner B (1976) Taking the naturalness out of natural disasters. Nature 260:566-567

Oberndorfer S et al (2007) Vulnerabilitätsanalyse und monetäre Schadensbewertung von Wildbachereignissen in Österreich. Berichte des Bundesforschungs- und Ausbildungszentrum für Wald, Naturgefahren und Landschaft 139, Wien

ON (2003) Eurocode 1: Einwirkungen auf Tragwerke - Teil 1-1: Allgemeine Einwirkungen - Wichten, Eigengewicht und Nutzlasten im Hochbau, Österreichisches Normungsinstitut, Wien

ON (2005a) Eurocode 1: Einwirkungen auf Tragwerke - Teil 1-4: Allgemeine Einwirkungen - Windlasten, Österreichisches Normungsinstitut, Wien

ON (2005b) Eurocode 1 - Einwirkungen auf Tragwerke - Teil 1-3: Allgemeine Einwirkungen, Schneelasten, Österreichisches Normungsinstitut, Wien

ON (2006a) Eurocode 1 - Einwirkungen auf Tragwerke - Teil 1-1: Allgemeine Einwirkungen - Wichten, Eigengewichte, Nutzlasten im Hochbau - Nationale Festlegungen zu ÖNORM EN 1991-1-1 und nationale Ergänzungen. Österreichisches Normungsinstitut, Wien

ON (2006b) Eurocode 1: Einwirkungen auf Tragwerke - Teil 1-4: Allgemeine Einwirkungen - Windlasten - Nationale Festlegungen zu ÖNORM EN 1991-1-4 und nationale Ergänzungen. Österreichisches Normungsinstitut, Wien

ON (2006c) Eurocode 1 - Einwirkungen auf Tragwerke - Teil 1-3: Allgemeine Einwirkungen - Schneelasten - Nationale Festlegungen zur ÖNORM EN 1991-1-3, nationale Erläuterungen und nationale Ergänzungen. Österreichisches Normungsinstitut, Wien

ONR (2007) Permanenter technischer Lawinenschutz - Benennungen und Definitionen sowie statische und dynamische Lastannahmen (Vorschlag, 27.08.2007). Österreichisches Normungsinstitut, Wien

ONR (2009) Schutzbauwerke der Wildbachverbauung - Begriffe und ihre Definitionen sowie Klassifizierung. Österreichisches Normungsinstitut, Wien

Papathoma-Köhle M et al (2011) Physical vulnerability assessment for alpine hazards: state of the art and future needs. Nat Hazards 58(2):645

Renfroe N, Smith J (2010) Threat/vulnerability assessments and risk analysis. http://www.buildingsecurity.us/odoc/usbuilding/ALL/ pdfs/RiskAssessmentMethodology.pdf. Accessed 12 November 2010

Romang H et al (2003) Control structures, vulnerability, costeffectiveness - a contribution to the management of risks from debris torrents. In: Rickenmann D, Chen C (eds) Debris-flow hazards mitigation: mechanics, prediction and assessment. Millpress, Rotterdam, pp 1303-1313

SLF (ed) (2000) Der Lawinenwinter 1999. Eidgenössisches Institut für Schnee- und Lawinenforschung, Davos

Smith K, Petley D (2009) Environmental hazards. Routledge, London

Solomon S et al (2007) Climate change 2007. The scientific basis: contribution of working group I to the fourth assessment report of the intergovernmental panel on climate change, Cambridge University Press, Cambridge

Sovilla B, Schaer M, Rammer L (2008) Measurements and analysis of full-scale avalanche impact pressure at the Vallée de la Sionne test site. Cold Reg Sci Technol 51:122-137

Statistik Austria (2004) Gebäude- und Wohnungszählung 2001: Hauptergebnisse Österreich. Statistik Austria, Wien

Susman O, O'Keefe P, Wisner B (1983) Global disasters: a radical interpretation. In: Hewitt $\mathrm{K}$ (ed) Interpretations of calamity. Allen and Unwin, Boston, pp 264-283

Totschnig R, Sedlacek W, Fuchs S (2011) A quantitative vulnerability function for fluvial sediment transport. Nat Hazards 58(2):681-703

Varnes D (1984) Landslide hazard zonation: a review of principles and practice. Natural Hazards. UNESCO, Paris

White G (1994) A perspective on reducing losses from natural hazards. Bull Am Meteorol Soc 75:1237-1240

Wilhelm C (1997) Wirtschaftlichkeit im Lawinenschutz. Mitteilungen des Eidgenössischen Instituts für Schnee- und Lawinenforschung. Eidgenössisches Institut für Schnee- und Lawinenforschung, Davos 